\title{
Analysis on Current Situation, Problems and Main Causes of College Japanese Teaching-Taking Jingdezhen Ceramic Institute as an Example
}

\author{
Yu Wu ${ }^{*}$, Danyu Wu \\ School of International Studies, Jingdezhen Ceramic Institute, Jingdezhen, 333000, China \\ * Corresponding Author: Yu Wu
}

Keywords: Japanese pronunciation, Japanese teaching, Jingdezhen Ceramic Institute

\begin{abstract}
The quality and quantity of Japanese teaching have been remarkably improved in in recent years with the increase of the number of students learning Japanese. However, the Japanese teaching has not yet got rid of the shackles of traditional teaching. There are still many deficiencies in the teaching of Japanese majors, especially the Japanese pronunciation teaching. The difficulties of Japanese pronunciation teaching lie in the factors of the dialect language transfer, psychology, teachers, the teaching aids and environment.
\end{abstract}

\section{Current Situation of College Japanese Teaching}

Currently, most colleges take English as the first foreign language in foreign language teaching in colleges. In the choice of second foreign languages, the first language still occupies the first place in the school, and most of the students have no Japanese basis. College Japanese students mostly start from Japanese pseudonym pronunciation and letter identification, without any Japanese basis. Compared with the Japanese professional courses, the opening time is shorter. The time of teaching is generally four hours a week, the length is two school years, and the short term is half a semester. With the rapid growth of China's economic strength and the increasing international status, the communication with neighboring Japan will be more extensive, and the demand for Japanese compound talents will continue to grow. Therefore, a lot of people regard Japanese as the first language of the second foreign language. For a long time, colleges and universities did not pay enough attention to Japanese teaching, and the funds were not in place. Many schools were backward in teaching facilities, and the teaching mode was single. They still stayed on textbooks, chalk and blackboard. Compared with the extensive and extensive English reference books, the Japanese books in the winter library seem insignificant, which directly leads to the lack of a good learning environment for foreign language learners. As most of the students studying Japanese have already mastered another foreign language, and most of the universities take Japanese as an elective course, there is no requirement for over grade, so most students do not attach enough importance to it. If they are easy to learn, they will choose Japanese course: some learners are interested in Japanese, and they like to see Japanese animation culture, Japanese dramas and so on. Learners who have different learning purposes are enthusiastic at the initial stage of their learning. Due to the lack of learning goals and pressures, the enthusiasm for learning Japanese later is not high. They study Japanese as a foreign language of postgraduate study. There are different degrees of emphasis on knowledge and light ability in college Japanese teaching in colleges. Some teachers regard the second language as a minor, who don’t spend enough energy and time in the second language teaching.

\section{Problems of College Japanese in Jingdezhen Ceramic Institute}

The author has conducted the investigation of Japanese pronunciation learning for many times in the teaching experience in recent years for the professional Japanese learners. The main content and main problems are shown as follows

\subsection{Late start of Pronunciation Teaching and Severe Interference of Mother Dialects}


For Japanese beginners who have just entered the university, they mainly use the Mandarin and their native dialect before contacting with the Japanese language. In the initial Japanese learning, many students were easily disturbed by such factors as the pronunciation of the dialect and native language. There are many of them which are lack of the differences between the retroflex and non-retroflex or the differences between the front nasals and back nasals throughout the different dialects in many locations of China. The Japanese learning statistical data of Jingdezhen Ceramic Institute is shown in Table 1.

Table 1. Japanese learning statistical data of Jingdezhen Ceramic Institute

\begin{tabular}{|c|c|c|}
\hline Learning difficulty & $\begin{array}{c}\text { Students fully mastering } \\
\text { it }\end{array}$ & Students cannot fully master it \\
\hline $\begin{array}{c}\text { Voiceless consonant } \\
\text { and voiced consonant }\end{array}$ & $29.8 \%$ & $70.2 \%$ \\
\hline Promote tone & $51.2 \%$ & $48.3 \%$ \\
\hline Difficult tone & $58.0 \%$ & $42.0 \%$ \\
\hline Long tone & $51.6 \%$ & $48.4 \%$ \\
\hline Intonation & $38.7 \%$ & $61.2 \%$ \\
\hline $\begin{array}{c}\text { Japanese } \\
\text { pronunciation }\end{array}$ & $62.9 \%$ & $37.1 \%$ \\
\hline
\end{tabular}

Among the students of Japanese majors in Jingdezhen Ceramic Institute, many students have come from the areas with sever dialect such as Sichuan, Hunan and so on. For many students in Hunan, the voiceless consonant, the voiced consonant, the Promote tone, the Long tone, the beat and the Intonation of the fifty tones are always big headaches.

The majority of students at Jingdezhen Ceramic Institute come from the dialect areas. It leads to a general deviation of the pronunciation of some of the students' words, or the odd pronunciation of certain words, which is difficult to correct.

According to the statistical data, Japanese pronunciation is difficult for most professional Japanese learners. Compared with the other two aspects of linguistics, which are the vocabulary and grammar, the theory research and practice at home and abroad on this aspect is obviously deficient. For the students coming from these areas, learning Japanese of these students are much more difficult than other students.

For the lower grade students, whether the pronunciation foundation is sound or not plays a decisive role in Japanese intensive reading study. If the students can't pronounce it, it will cause serious influence on the memory, reading and listening of the intensive reading in the future.

\subsection{Single Teaching Model and Low Attention Degree of Teachers}

Due to the restriction of traditional teaching ideas, the Japanese intensive reading courses of the students of junior grade learning Japanese often adopt the traditional teaching model. It is a kind of teaching model which is mainly based on mainly teachers' teaching with students' imitation as the supplement.

In this teaching model, some teachers do not pay enough attention to the pronunciation, but pay a lot attention on the grammar teaching. Some Japanese teachers imitate English teaching in senior high school. They only teach the grammar and do not practice any listening.

Due to the small number of Japanese teachers, many Japanese teachers have a quietly heavy teaching task. Some teachers just want to complete the task of teaching grammar, and ignore the pronunciation. This kind of "passive" teaching model is not only bad for students to absorb knowledge, but also easy to make students feel resentful.

Through the investigation of low grade students in recent years, the author found that the practice of blindly echo what the books say would decrease the participation of students. It cannot exert the 
subjective initiative of the students, leading to the unsatisfied teaching effect. Students who are lack of the autonomous learning awareness in Japanese pronunciation will have a bade mastery of the Japanese pronunciation. The students don't have the review habits, leading to the forgetting. The students will get half the results with twice the effort under the teaching model.

\subsection{Old-fashioned Teaching Materials and Shallow Research Depth}

Compared with the phonetic research of specialized Japanese teaching, the related papers and works of pronunciation teaching of college Japanese are obviously deficient. The teaching content is too rigid and the teaching effect is poor.

Especially for the current Japanese intensive reading class of low grades, the main teaching contents are composed of main word teaching with grammar teaching as supplement. Taking a look at the teaching content of Japanese intensive reading materials in the main universities in China, it is generally relatively old and lacks innovation. Many words are difficult to link up with current affairs and life. It leads to boring motion and low enthusiasm of the students. The quality of teaching has also declined.

\section{Main Reasons for the Misunderstandings of Japanese Pronunciation}

The reasons for the pronunciation misunderstands of the Japanese learners in our institute in the long tone, the voiced tone, the difficult tone, the promote tone and the intonation lie in many aspects. The students are the subjects of the teaching process, especially for the college students coming from the central China. It is of significant importance for the college Japanese teaching in the areas of central China.

\subsection{Language Transfer}

Language transfer is an important factor in language learning. The positive transfer of language promotes the second foreign language acquisition, and the negative transfer of language interferes with the second foreign language acquisition.

With the development of Japanese learners' proficiency, the transfer of mother tongue and target language can also occur in the second foreign language acquisition. The study of language transfer is of guiding significance to Japanese phonetics teaching. The influence of dialect and acquired language cannot be ignored.

There are many similarities between these languages and ancient Chinese. It is very meaningful for Japanese learners to study the Japanese language which has many similarities with ancient Chinese. But at the same time, it is very easy for a few negative transfer phenomena of Japanese speech. For example:

In Mandarin, [1] and [n] are the middle of the tip of the tongue. When they pronounce, the vocal cords vibrate, and they all belong to the voiced sound. According to the Constitution and eliminate obstacles in different ways, [1] should belong to the laterals, the tip of your tongue against the upper gum, on both sides of the gap left by the rising soft palate nasal pathway, the outflow of air from the tongue on both sides into sound; [n] as a pronunciation, pronunciation is not completely closed, the air through the nose outflow into sound. Mandarin, however, the word beginning with [n] in many dialects is read as [1].

In the Wu Dialect, the most common case is that the anterior nasal sounds completely replace the posterior nasal sounds, which makes it difficult for the Japanese to pronounce the h. In Mandarin, some learners mistake "shuiwangwang” for "shuiwanwan" and "pengyou” for "penyou”. The close accent and the open accent of [h] are not distinguished. In the Gan Dialect, the people always confuse [h] and [f]. For example, the Gan Dialect always mistake [hua] for [fa] and [fan] for [huan]. At the same time, as one of the most important foreign languages for Chinese people, English belongs to the first foreign language according to the order of language acquisition. Therefore, the influence of English pronunciation, especially for Japanese majors in English major, is particularly profound.

A large number of foreign words in Japanese have greatly improved the convenience of Japanese 
learners who have the basis of English language. The author has done an experiment. In the circumstance that the students did not contact with any Japanese, the author gave twenty Japanese words originated from English for the students to guess the meaning of each word. Surprisingly, the correct rate is $77.5 \%$. It is almost impossible for the students to learn other language.

However, the negative migration also exists simultaneously. In terms of the vowels, English vowels are divided into long and short notes. The opening degree of English vowel is generally larger than that of the Japanese. Therefore, a lot of English major Japanese learner's pronunciation is slightly larger than the standard Japanese. There are many cacuminal in the pronunciation of English consonants, which make a lot of fluent oral English Japanese learners' pronunciation phonemes back. In terms of the English tone, English pays attention to a sing-song voice. The Japanese learners who have a good command of English language are prone to speak "American Japanese".

\subsection{Psychological Factors}

In the teaching of Japanese pronunciation, in addition to the negative influence of dialect and negative transfer of English, there are also psychological factors. Some students think that learning grammar of Japanese is learning Japanese with an enough attention psychology. Some students have anxiety and are fear of reading to be laughed by the teachers and the students. The strong anxiety and fear hindered the necessary practice of Japanese speech. Voice mastery requires a lot of repetition and practice. Before reaching the standard Japanese pronunciation, it is bound to go through a long process of struggling with the wrong pronunciations. Without powerful motivation and determination, it is difficult to completely grasp the phonetic part of the language.

\subsection{Teachers Factors}

Many teachers have been influenced by the dialect, which is difficult to give the students a correct demonstration during teaching. Some teachers do not pay enough attention to pronunciation and pay too much attention to grammar and the students' ability to take exams. It resulted in many students' "Deaf Mute Japanese" and "Mechanical Test Japanese"'". Japanese listening and speaking ability is much lower than other Japanese abilities.

\subsection{Teaching Aids and Environment}

Comparatively speaking, the importance of Japanese majors in engineering institute is often less than that of the specialized courses. The limited resources of multimedia classrooms in colleges and universities directly result in the unsatisfactory learning environment for Japanese learners.

\section{Conclusion}

The teaching of college Japanese is not an easy thing. Teachers should cultivate interest and confidence in Japanese learning, and help them master good Japanese learning methods. Teachers should formulate teaching methods suitable for themselves according to the specific conditions of the colleges and the actual situations of the students.

\section{References}

[1] Yang J. Analysis on Cultural Differences and Acculturation in Japanese Teaching[J]. The World and Chongqing, 2014, 7: 021.

[2] Hui R, Jiang W. Exploration of New Japanese Teaching Models in Private Universities: A Case Study on Japanese International Characteristic Class in Beijing City University[J]. The Science Education Article Collects, 2014, 10: 066.

[3] HUANG H, PU X, CAO W. Constuction of an Ergonomics Experimental Teaching Model Based on Japanese Teaching Experience[J]. Research and Exploration in Laboratory, 2013, 2: 044.

[4] De Crée C. Shōnen Jūdō-no-kata ['Forms of Jūdō for Juveniles']: an experimental Japanese 
teaching approach to jūdō skill acquisition in children considered from a historic-pedagogical perspective-part 1[J]. Journal of Combat Sports and Martial Arts, 2013, 4(1): 1-13. 